\section{Postharvest Handling of Cut Campanula medium Flowers}

\author{
Theresa Bosma ${ }^{1}$ and John M. Dole ${ }^{2}$ \\ Department of Horticulture and Landscape Architecture, Oklahoma State \\ University, Stillwater, OK 74078-6027
}

Additional index words. Canterbury bells, bell flower, storage, sucrose solution, floral vase substrate, light intensity, vase life

Abstract. Various postharvest treatments were evaluated for effect on longevity and quality of cut Campanula medium $\mathrm{L}$. 'Champion Blue' and 'Champion Pink' stems. Stems stored at $2{ }^{\circ} \mathrm{C}$ either wet or dry had no difference in vase life or percent flowers opened; however, flowers stored dry had a slightly greater percentage of senesced flowers at termination. Increasing storage duration from 1 to 3 weeks decreased vase life. Stems pretreated for 4 hours with $38^{\circ} \mathrm{C}$ floral solution (deionized water amended to $\mathrm{pH} 3.5$ with citric acid and $200 \mathrm{mg} \cdot \mathrm{L}^{-1} 8-\mathrm{HQC}$ ) or a 1-MCP pulse followed by a $5 \%$ sucrose pulse solution produced the longest vase life (10.3 or 10.4 days, respectively). Flowers opening after treatments commenced were paler than those flowers already opened and a 24-hour pretreatment with $5 \%$ or $10 \%$ sucrose did not prevent this color reduction. Stems had an average vase life of only 3.3 days when placed in floral vase foam but lasted 10.0 days without foam. Optimum sucrose concentration was $1.0 \%$ to $2.0 \%$ for stems placed in $22{ }^{\circ} \mathrm{C}$ floral vase solution without foam and $4 \%$ for stems placed in foam. High (110 $\left.\mu \mathrm{mol} \cdot \mathrm{m}^{-2} \cdot \mathrm{s}^{-1}\right)$ or low $\left(10 \mu \mathrm{mol} \cdot \mathrm{m}^{-2} \cdot \mathrm{s}^{-1}\right)$ light levels did not affect postharvest parameters, but the most recently opened flowers were paler under low light conditions than under high light conditions. Chemical names used: 8-hydroxyquinoline citrate (8-HQC); 1-methylcyclopropene (1-MCP).

Specialty cut flowers have been growing in popularity with the industry and consumers for the last several years [U.S. Dept. of Agriculture (USDA), 2000]. Carnations (Dianthus caryophyllus L.), chrysanthemums [Dendranthema $\times$ grandiflora (Ramat.) Kitam.], and roses (Rosa L.), which have been the mainstay of the cut flower industry for years, were "down sharply" in 1999 as part of a continuing trend (USDA, 2000). Continued success of specialty cut flowers requires the introduction of new species. Campanula medium, commonly known as Canterbury bells, is a biennial plant commonly used in gardens in the United States and sold as flowering potted plants in Europe (Dole and Wilkins, 1999). Flower color is blue or lavender, pink, and white. The inflorescence is a raceme of 2.5-cm-long, cup-shaped flowers creating an unusual shape not common in cut flowers (Fig. 1). One to several inflorescences of up to 75 $\mathrm{cm}$ long arise from pubescent plants with rosulate lower leaves; each inflorescence has 10 or more flowers (Fig. 2). 'Champion Blue' and 'Champion Pink' were bred specifically for cut flower production. They have a short crop time, typically flowering in 18 to 23 weeks, making it possible to grow and sell this

Received for publication 1 Aug. 2001. Accepted for publication 7 Dec. 2001. Approved for publication by the Director, Oklahoma Agricultural Experiment Station (OAES). Our research was supported in part by OAES under project H-2119. We thank Leah Aufill for technical assistance and Sakata Seed America for financial support and flowers.

${ }^{1}$ Graduate Research Assistant.

${ }^{2}$ Professor; currently at Dept. of Horticultural Science, North Carolina State Univ., Campus Box 7609, Raleigh, NC 27695-7609. normally biennial plant in a cost-effective time period (Cavins, 1999). However, limited research has examined the postharvest life of cut Campanula flowers (Sakata Seed America, personal communication).

Storing cut Campanula stems in coolers benefits the grower, wholesaler, and florist by extending the production season, allowing storage of excess production, improving production efficiency, and enabling long-term shipment (Goszczynska and Rudnicki, 1988). Recommended storage temperatures for cut flowers depend on the particular species and cultivar, but generally vary between 0 and $4{ }^{\circ} \mathrm{C}$ (Nowak and Rudnicki, 1990). Cut Campanula stems could either be stored wet in water or

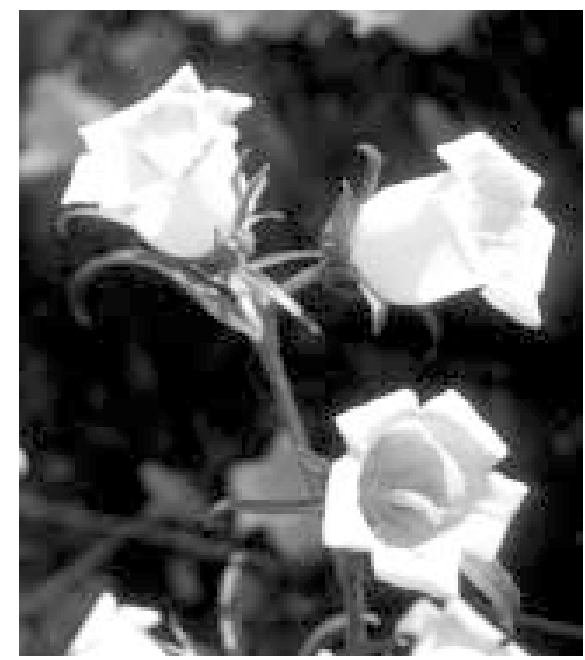

Fig. 1. Campanula medium flowers. preservative solution or dry in a polyethylene plastic or wax-lined box (Nowak and Rudnicki, 1990).

Vase life can be extended by pretreatments and pulses, which are short-term treatments (generally $24 \mathrm{~h}$ or less) conducted just after harvest. A pretreatment may consist of placing stems in heated water $\left(\approx 38{ }^{\circ} \mathrm{C}\right)$ to enhance water absorption or applying an anti-ethylene compound, such as silver thiosulfate (STS) or 1-MCP (Serek et al., 1995). Cut Campanula stems are sensitive to ethylene, which causes open petals to brown and shrivel and buds to discolor and die, and anti-ethylene compounds may prevent ethylene damage (Hunter et al., 2001; Woltering and van Doorn, 1988).

Cut Campanula stems may benefit from the addition of sucrose to increase rate and number of Campanula buds opening, improve petal coloration, especially for the dark purple cultivar 'Champion Blue', and extend vase life (Halevy and Mayak, 1979; Nowak and Rudnicki, 1990; Sacalis, 1993). Sucrose can be applied in pulse solutions of $0.5 \%$ to $25 \%$ from a few hours to $2 \mathrm{~d}$ (Goszczynska and Rudnicki, 1988) or in vase solutions of $0.5 \%$ to $7 \%$. With the presence of sucrose, addition of a germicide such as 8-HQC is necessary to inhibit microbial growth (Sacalis, 1993). Not only is 8-HQC effective against microbes, it is also slightly acidic, which benefits water absorption (Sacalis, 1993).

Low light conditions after harvest can reduce flower color development in certain species. Incomplete coloration of petals has been correlated with purple cultivars of Eustoma grandiflorum Griese. under low light conditions after stem harvest (Griesbach, 1992; Kawabata et al., 1995). Campanula 'Champion Blue' also has purple petals, and high light intensity in the postharvest environment may enhance petal coloration.

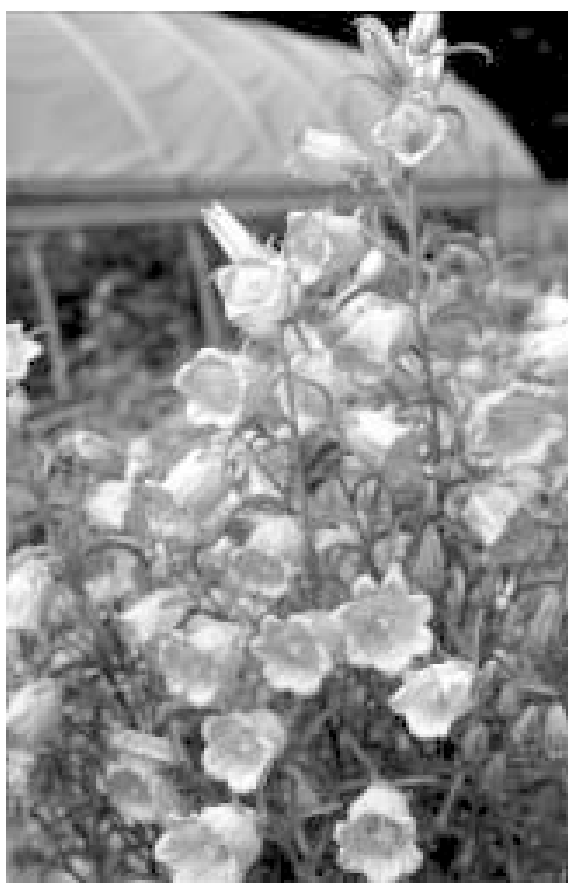

Fig. 2. Campanula medium 'Champion Pink' inflorescences. 
Objectives of this research were to maximize C.medium 'Champion' storage life, color development in flowers opening after harvest, and vase life for the retailer and consumer through the use of cold storage, 1-MCP, sucrose, and floral foam.

\section{Materials and Methods}

Cut stems of C. medium 'Champion Blue' and 'Champion Pink' were obtained from Burdette and Coward Co., Punta Gorda, Fla. Stems were placed in unamended tap water after harvest and cooled at $2{ }^{\circ} \mathrm{C}$ until shipped dry overnight on 5 Jan. 2000. Insufficient 'Champion Blue' stems were available for all four experiments; consequently, 'Champion Blue' stems were used in Expts. 1, 3, and 4 and 'Champion Pink' stems were used in Expt. 2. Upon arrival, boxed stems were held at $2{ }^{\circ} \mathrm{C}$ until processed the same day for experiments. All stems were recut under water and then placed in the appropriate treatment. Unless otherwise indicated, the solution (floral solution) used in all experiments was $22^{\circ} \mathrm{C}$ deionized water $\left(0.1 \mathrm{dS} \cdot \mathrm{m}^{-2} \mathrm{EC}\right)$ amended to $\mathrm{pH} 3.5$ using citric acid and $200 \mathrm{mg} \cdot \mathrm{L}^{-1} 8$-HQC. Sterile glass vases that held $\approx 180 \mathrm{~mL}$ floral solution were used in all experiments. Holding room air temperature averaged $19 / 24^{\circ} \mathrm{C}$ minimum/maximum, and light level averaged 110 $\mu \mathrm{mol} \cdot \mathrm{m}^{-2} \cdot \mathrm{s}^{-1}$ from fluorescent lamps. The following parameters were measured in each experiment: number of flowers per stem open prior to treatment, number of flowers per stem open during treatment, vase life after removal from treatment, and number of senesced flowers per stem at the time the vase life of each stem was terminated. Individual florets were considered senesced when more than $50 \%$ of the corolla was necrotic or wilted. Stems were terminated when half of the florets had senesced or the stem collapsed. Flower color (value, hue, and chroma) was measured (Minolta CR200 chroma meter; Minolta Corp., Ramsey, N.J.) during Expts. 2 and 4 one week after treatment commenced on a flower open prior to treatment (first flower) and on the most recently opened flower (second flower). Value is a measure of the color's lightness or darkness. Hue represents the actual colors found on a color wheel, i.e., red, blue, green, and yellow. Chroma conveys the vividness or dullness of a certain color (Minolta Corp., 1985). Chroma meters measure and quantify value, hue, and chroma, allowing objective comparisons among treatments (Hunter, 1942).

Prior to placement in the treatments, stems were sorted by the number of opened flowers (4-9 flowers/stem), and treatments blocked accordingly. Fifteen repetitions (flower stems) were used for each treatment, except for Expt. 2 in which 12 repetitions were used. Data were subjected to the general linear model procedure, and means separation was accomplished by trend analysis or Duncan's multiple range test (SAS Institute, Cary, N.C.). Percentage data were transformed using the arcsin procedure prior to statistical analysis.

Cold storage duration (Expt. 1). Cut stems were held $0,1,2$, or 3 weeks in a $2{ }^{\circ} \mathrm{C}$ cooler
Table 1 . Effect of $0,1,2$, or 3 weeks $2{ }^{\circ} \mathrm{C}$ cold storage on postharvest quality of Campanula medium 'Champion Blue'. Values shown are means of 30 to 60 stems.

\begin{tabular}{lcc}
\hline $\begin{array}{l}\text { Storage } \\
\text { duration } \\
\text { (weeks) }\end{array}$ & $\begin{array}{c}\text { Vase life } \\
(\mathrm{d})\end{array}$ & $\begin{array}{c}\text { Flowers opened } \\
\text { during storage } \\
(\%)\end{array}$ \\
\hline 0 & 10.4 & 0.0 \\
1 & 8.4 & 19.6 \\
2 & 6.5 & 14.7 \\
3 & 6.1 & 19.8 \\
Significance & $\mathrm{L}^{* * * *}$ & $\mathrm{~L}^{* * *} \mathrm{Q}^{* * *} \mathrm{C}^{* * *}$ \\
\hline
\end{tabular}

${ }^{* * *}$ Significant at $P \leq 0.001$; linear (L), quadratic (Q), or cubic (C).

(average relative humidity $86 \%$ ) either dry or wet. For dry storage, stems were placed in boxes lined with paper and plastic. Wet stems were placed in sterile floral buckets filled with floral solution. The 0 -week storage stems were placed directly into floral vases in the holding room. At weeks 1, 2, and 3, 15 stems were randomly selected from each treatment, recut under water, and placed in floral vases filled with floral solution. All remaining stems were recut under water and placed back into their respective treatments. Stems had an average of 16.3 florets/stem, with $44 \%$ of florets fully colored and opened prior to treatment. Floral solution was changed in buckets for the wet treatment prior to return of the stems. The experimental design was a randomized complete block.

Pretreatments and pulses (Expt. 2). Cut stems received three different 4-h pretreatment methods: 1) floral solution heated to 38 ${ }^{\circ} \mathrm{C}$; 2) 1-MCP (Ethylbloc; BioTechnologies for Horticulture, Burr Ridge, Ill.) and $22^{\circ} \mathrm{C}$ floral solution; or 3) $22{ }^{\circ} \mathrm{C}$ floral solution. After pretreatments, stems received a $24-\mathrm{h}$ pulse treatment of $0 \%, 5 \%$, or $10 \%$ sucrose in floral solution and then were placed in the holding room. For 1-MCP application, $2 \mathrm{~g}$ were added to $20 \mathrm{~mL}$ buffer agent releasing 1MCP gas into $60 \mathrm{~m}^{3}$ of enclosed air space. Chroma meter readings were taken 1 week after the stems had been in the floral vases. The experiment was a completely randomized design.

Vase solutions and substrates (Expt. 3). Cut stems were placed in vases with or without floral foam (Aquafoam Instant, Syndicate Sales, Kokomo, Ind.) and 0\%, 0.5\%, 1\%, 2\%, or $4 \%$ sucrose in floral solution in the holding room. Foam was allowed to thoroughly soak in the respective solution before placement in vase. A completely randomized design was used.

Light levels(Expt.4).Cut stems were placed in floral solution and exposed to either 10 or $110 \mu \mathrm{mol} \cdot \mathrm{m}^{-2} \cdot \mathrm{s}^{-1}$ light; light levels were determined by varying the distance from the fluorescent lamps in the holding room. Chroma meter readings were taken 1 week after placement in the treatments.

\section{Results}

Cold storage duration (Expt. 1). Increasing cold storage duration linearly reduced vase life (Table 1). A curvilinear response was
Table 2. Effect of dry (D) or wet (W) and $0,1,2$, or 3 weeks $2{ }^{\circ} \mathrm{C}$ cold storage (S) on percentage of senesced Campanula medium 'Champion Blue' flowers at vase life termination. Values shown are means of 15 stems.

\begin{tabular}{lcc}
\hline \hline Storage type & $\begin{array}{c}\text { Storage } \\
\text { duration } \\
\text { (weeks) }\end{array}$ & $\begin{array}{c}\text { Senesced flowers at } \\
\text { vase life termination } \\
(\%)\end{array}$ \\
\hline Dry (D) & 0 & 0.0 \\
& 1 & 2.6 \\
& 2 & 3.6 \\
Wet (W) & 3 & 5.9 \\
& 0 & 0.0 \\
& 1 & 1.1 \\
& 2 & 0.5 \\
& 3 & 0.5
\end{tabular}

Storage type

**

Storage duration (S)

Significant interactions $(P \leq 0.05)$ $\mathrm{D} \times \mathrm{S}$

$\mathrm{W} \times \mathrm{S}$

,**Nonsignificant or significant at $P \leq 0.05$ or 0.01 , respectively; linear $(\mathrm{L})$.

evident for the percentage of flowers that opened during cold storage, such that weeks 1 and 3 had the largest percentages, while week 2 exhibited the lowest percentage (Table 1). Storage method did not affect vase life or the percentage of flowers opening (data not presented). An increasing number of flowers were senesced at vase life termination as the duration of dry storage increased and the number of flowers senesced was higher for dry storage than for wet (Table 2).

Pretreatments and pulses (Expt. 2). Pretreatments and pulses interacted such that the longest vase life resulted from the 5\% sucrose pulse combined with the 1-MCP pretreatment (10.4 d) or $38^{\circ} \mathrm{C}$ floral solution (10.3 d), but vase life was only $3.6 \mathrm{~d}$ when the $38{ }^{\circ} \mathrm{C}$ treatment was used in combination with $10 \%$ sucrose pulse (Table 3). Pretreatment and pulse methods interacted such that increasing sucrose concentration increased the percentage of flowers senesced at the end of vase life with all three pretreatments, but the greatest increase in senesced flowers occurred with increasing sucrose concentration within the 38 ${ }^{\circ} \mathrm{C}$ pretreatment (Table 3 ).

Increasing sucrose concentration in the pulse solution linearly decreased the percentage of flowers opening during treatment (Table 4). Treatments with $0 \%$ sucrose stimulated the greatest percentage $(26.0 \%)$ of open flowers, while $10 \%$ sucrose produced the lowest percentage $(9.5 \%)$. Pretreatment methods did not affect the percentage of flowers opening (data not presented).

Flowers opened at the time treatments commenced became paler and less intensely colored with increasing sucrose concentration (Table 5). Increasing sucrose concentration curvilinearly increased value and chroma and decreased hue of the second measured flower; flowers in the $5 \%$ sucrose treatment were paler than those in the $0 \%$ or $10 \%$ sucrose. Flowers that opened after treatments commenced were paler than flowers opened at the time of harvest. Pretreatment methods did not significantly $(P \leq 0.5)$ affect flower value, hue, or chroma (data not presented). 
Table 3. Effect of $4-\mathrm{h} 20^{\circ} \mathrm{C}$ unheated (U) or $38^{\circ} \mathrm{C}$ heated (H) floral solution or 1-methylcyclopropene (M) pretreatments followed by 24-h $0 \%, 5 \%$, or $10 \%$ sucrose pulses (S) on postharvest quality of Campanula medium 'Champion Pink'. Values shown are means of 12 stems.

\begin{tabular}{|c|c|c|c|}
\hline Pretreatment & $\begin{array}{c}\text { Sucrose } \\
\text { pulse } \\
(\%)\end{array}$ & $\begin{array}{l}\text { Vase } \\
\text { life } \\
\text { (d) } \\
\end{array}$ & $\begin{array}{c}\text { Senesced flowers } \\
\text { at vase life termination } \\
(\%)\end{array}$ \\
\hline \multirow[t]{3}{*}{ Unheated (U) } & 0 & 9.1 & 5.4 \\
\hline & 5 & 7.8 & 14.4 \\
\hline & 10 & 8.8 & 19.0 \\
\hline \multirow[t]{3}{*}{$38^{\circ} \mathrm{C}(\mathrm{H})$} & 0 & 7.3 & 1.1 \\
\hline & 5 & 10.3 & 6.8 \\
\hline & 10 & 3.6 & 43.2 \\
\hline \multirow[t]{3}{*}{ 1-MCP (M) } & 0 & 7.8 & 1.4 \\
\hline & 5 & 10.4 & 12.2 \\
\hline & 10 & 9.7 & 24.4 \\
\hline \multicolumn{2}{|l|}{ Pretreatment } & $*$ & NS \\
\hline \multicolumn{2}{|l|}{ Pulse (S) } & $\mathrm{Q}^{*}$ & $\mathrm{~L}^{* * *}$ \\
\hline \multicolumn{4}{|c|}{ Significant interactions $(P \leq 0.05)$} \\
\hline $\mathrm{U} \times \mathrm{S}$ & & None & $\mathrm{L}$ \\
\hline $\mathrm{H} \times \mathrm{S}$ & & $\mathrm{L}, \mathrm{C}$ & $\mathrm{L}, \mathrm{C}$ \\
\hline $\mathrm{M} \times \mathrm{S}$ & & None & None \\
\hline
\end{tabular}

Table 4. Effect of $0 \%, 5 \%$, or $10 \%$ sucrose pulses on postharvest quality of Campanula medium 'Champion Pink'. Values shown are means of 36 stems.

\begin{tabular}{lc}
\hline $\begin{array}{l}\text { Sucrose } \\
\text { pulse }\end{array}$ & Flowers opened during treatment \\
$(\%)$ & $(\%)$ \\
\hline 0 & 26.0 \\
5 & 22.8 \\
10 & 9.5 \\
Significance & $\mathrm{L}^{* * *}$ \\
\hline
\end{tabular}

**** Significant at $P \leq 0.001$; linear (L).
Vase sucrose and substrates (Expt. 3). Floral vase substrate and sucrose concentration interacted such that stems in the no-foam treatment with $2.0 \%$ sucrose had the longest vase life (12.2 d), but the shortest vase life occurred with foam and $0.5 \%(2.3 \mathrm{~d})$ or $1.0 \%$ sucrose (2.4 d) (Fig. 3). Floral vase substrate and sucrose concentration interacted to create the largest percentage of flowers senesced $(46.2 \%)$ at the end of vase life in the no-foam treatment with $4.0 \%$ sucrose (Fig. 3). The treatment combination of foam with $0.5 \%$ sucrose was the only treatment to yield no senesced flowers, due to rapid death of the stem (2.3 d).

Light levels (Expt. 4). Under low light, the second measured flower was paler in color, less intense, and less vivid compared with the second measured flower under high light treatment (Table 6). Light level did not significantly affect vase life or percentage of senesced flowers at vase life termination (data not presented). High and low light levels did not significantly affect value, hue, or chroma for the first flower that was measured.

\section{Discussion}

Cold storage duration. While dry storage may be commercially acceptable, wet storage is preferred because dry storage increased the

Fig. 3. (right) Effect of floral foam (FF) or no floral foam (NF) substrate and $0,0.5 \%, 1.0 \%, 2.0 \%$, or $4.0 \%$ sucrose (S) solution on postharvest quality of Campanula medium 'Champion Blue'. Values shown are means of 15 stems. Significance for vase life: substrate $(P \leq 0.001)$, solution (linear $P \leq 0.05$, quadratic $P \leq 0.01$ ), and interactions with $P \leq 0.05: \mathrm{FF} \times \mathrm{S}$ linear $(P \leq 0.001)$ and $\mathrm{NF} \times \mathrm{S}$ quadratic $(P \leq 0.001)$. Significance for percentage of senesced flowers at vase life termination: substrate $(P \leq 0.01)$, solution (linear $P \leq 0.001$, quadratic $P \leq 0.05)$ and interactions with $P \leq 0.05$ : $\mathrm{NF} \times \mathrm{S}$ (linear $P \leq 0.001)$ and $\mathrm{NF}$ $\times \mathrm{S}$ quadratic $(P \leq 0.001)$.
Table 5. Effect of $0.0 \%, 5.0 \%$, or $10.0 \%$ sucrose pulses on chroma meter readings of Campanula medium 'Champion Pink' flowers. Values shown are means of 12 stems measured 1 week after stems were placed in floral vases on a flower open prior to treatment (first flower) and on the most recently opened flower (second flower) after placement in postharvest environment.

\begin{tabular}{|c|c|c|c|c|c|c|}
\hline \multirow{2}{*}{$\begin{array}{l}\text { Sucrose pulse } \\
(\%)\end{array}$} & \multicolumn{2}{|c|}{ Value } & \multicolumn{2}{|c|}{ Hue } & \multicolumn{2}{|c|}{ Chroma } \\
\hline & 1st flower & 2nd flower & 1st flower & 2nd flower & 1st flower & 2nd flower \\
\hline$\overline{0}$ & 57.6 & 65.3 & 14.0 & 4.3 & -5.1 & 0.6 \\
\hline 5 & 60.2 & 66.1 & 11.7 & 7.5 & -4.4 & -2.1 \\
\hline 10 & 61.6 & 66.1 & 10.5 & 6.3 & -4.2 & -1.6 \\
\hline Significance & $\mathrm{L}^{* *}$ & NS & $\mathrm{L}^{* *}$ & $\mathrm{Q}^{*}$ & $\mathrm{~L}^{*}$ & $\mathrm{~L}^{*} \mathrm{Q}^{*}$ \\
\hline
\end{tabular}

Ns, *, ** Nonsignificant or significant at $P \leq 0.05$ or 0.01 , respectively; linear (L) or quadratic (Q).

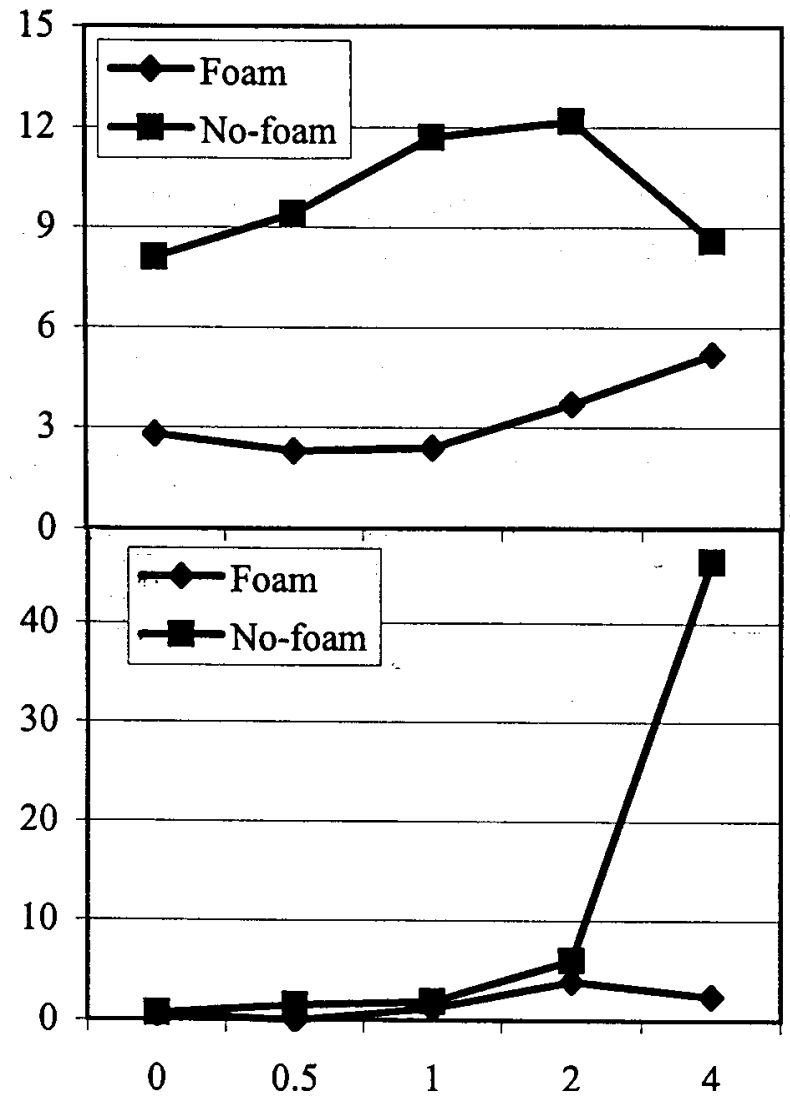

HortScience, Vol. 37(6), OCtober 2002 
Table 6. Effect of high $\left(110 \mu \mathrm{mol} \cdot \mathrm{m}^{-2} \cdot \mathrm{s}^{-1}\right)$ or low $\left(10 \mu \mathrm{mol} \cdot \mathrm{m}^{-2} \cdot \mathrm{s}^{-1}\right)$ light intensity on chroma meter readings of Campanula medium 'Champion Blue'. Values shown are means of 15 stems measured 1 week after stems were placed in floral vases on a flower open prior to treatment (first flower) and on the most recently opened flower (second flower).

\begin{tabular}{|c|c|c|c|c|c|c|}
\hline \multirow[b]{2}{*}{ Light intensity } & \multicolumn{2}{|c|}{ Value } & \multicolumn{2}{|c|}{ Hue } & \multicolumn{2}{|c|}{ Chroma } \\
\hline & 1st flower & 2nd flower & 1st flower & 2nd flower & 1st flower & 2nd flower \\
\hline High & 32.9 & 51.0 & 19.4 & 10.2 & -23.7 & -13.9 \\
\hline Low & 34.4 & 60.0 & 21.7 & 5.7 & -25.5 & -7.7 \\
\hline Significance & NS & $*$ & NS & $*$ & NS & $*$ \\
\hline
\end{tabular}

ss, * Nonsignificant or significant at $P \leq 0.05$.

percentage of senesced flowers at termination (Table 2). Increasing storage duration decreased vase life. Thus, while cold storage is not optimum, it may be commercially necessary and should be limited to 1 week or less. Long term storage often decreases vase life (Jones and Faragher, 1991; Kelly and Starman, 1990; Sacalis, 1993).

Interestingly, many florets $(18 \%)$ continued to open and color while in storage (Table 1). Apparently, $2{ }^{\circ} \mathrm{C}$ was not low enough to halt further development; lower storage temperatures may allow longer storage while still achieving acceptable vase life and quality. Storage temperatures less than $2{ }^{\circ} \mathrm{C}$ are also recommended for numerous other cut flower species, including -1 to $0{ }^{\circ} \mathrm{C}$ for lily-of-thevalley (Convallaria majalis L.) and carnation, and 0 to $1^{\circ} \mathrm{C}$ for gardenia [Gardenia angusta (L.) Merrill.], narcissus (Narcissus pseudonarcissus L.), and peony (Paeonia lactiflora Pall.) (Dole and Wilkins, 1999; Sacalis, 1993).

Pretreatments and pulses. The optimum sucrose concentration for pulsing was $5 \%$ when combined with $38{ }^{\circ} \mathrm{C}$ or 1-MCP pretreatment (Table 3). Stems that received $10 \%$ sucrose pulse solutions responded poorly regardless of the pretreatment used, producing the highest percentage of senesced flowers and lowest percentage of flowers opening during treatment (Tables 3 and 4). High sucrose concentrations have been deleterious to other cut flowers, such as chrysanthemums and roses (Halevy et al., 1978; Kofranek and Halevy, 1980). Treatments that used no sucrose yielded the lowest percentage of senesced Campanula flowers but had a shorter vase life than stems treated with $5 \%$ sucrose.

Pretreatment with $38{ }^{\circ} \mathrm{C}$ water or $1-\mathrm{MCP}$ was beneficial only when combined with $5 \%$ sucrose pulse (Table 3). Heated water promoted excessive sucrose uptake at the $10 \%$ concentration as evidenced by the high percentage of senesced flowers at vase life termination $(43.2 \%)$. Interestingly, while $C$. $m e$ dium flowers are sensitive to external ethylene (Hunter et al., 2001), 1-MCP increased vase life compared with unpretreated control flowers only when used in combination with $5 \%$ or $10 \%$ sucrose. Sisler et al. (1996) found a more dramatic effect of 1-MCP when they noted that potted $C$. carpatica Jacq. 'Blue Chips' display life increased from $3.3 \mathrm{~d}$ for untreated plants to $9.0 \mathrm{~d}$ when previously treated with 1 MCP for $6 \mathrm{~h}$. However, Sisler et al. (1996) also exposed the plants to $0.5 \mu \mathrm{L} \cdot \mathrm{L}^{-1}$ ethylene, which enhanced the difference in postharvest life between plants with or without 1-MCP treatment.
Flowers opening after treatments commenced were paler than those flowers already opened and none of the treatments prevented the color reduction in flowers opening after treatment (Table 5). In fact, increasing levels of sucrose resulted in a paler, grayer color for those flowers open at time of treatment. Higher sucrose levels reduced vase life (Table 3 ) for flowers not pretreated and may have accentuated color loss of the first flower measured due to more rapid senescence. Flowers unopened at treatment time responded differently to sucrose levels than already-open flowers (Table $5)$. Color for the second flower was paler for the $5 \%$ sucrose pulse treatment than the $0 \%$ or $10 \%$ treatments. Apparently, flowers unopened and not colored when placed into the 24-h 5\% sucrose treatment failed to develop full color when they did open, compared to flowers already colored and opened when placed into the treatment. In contrast, Kawabata et al. (1995) indicated that sucrose solutions $(0.125$, 0.25 , or $0.5 \mathrm{M}$ ) were beneficial for full-color development for unopened $E$. grandiflorum flower buds after they were detached at the peduncle. Full color development in unopened Campanula flowers may be possible with a 24-h pulse containing sucrose concentrations lower than $5 \%$ but greater than $0 \%$.

Vase sucrose and substrates. Overall, the no-foam stems had the longest vase life and lowest percentage of senesced flowers with either $1.0 \%$ or $2.0 \%$ sucrose solution (Fig. 3 ). Han (1998) found that cut Heuchera sanguinea Engelm. flowers had a longer vase life and higher percentages of opening buds at $0.5 \%$ or $1.0 \%$ sucrose compared to higher sucrose concentrations, but stem collapse increased at greater than $1.0 \%$ sucrose. Cut Triteleia laxa Benth. stems had a vase life of $12 \mathrm{~d}$ when held in solutions containing $2.0 \%$ sucrose, but vase life decreased as sucrose concentrations increased (Han et al., 1990).

Stems inserted into foam, regardless of the sucrose solution percentage, performed poorly; buds failed to open and vase life was only 2.3 to $5.2 \mathrm{~d}$ (Fig. 3). The Campanula stems may have been unable to take up sufficient solution in the foam to sustain themselves, but when $4.0 \%$ sucrose was used, stems were able to absorb enough carbohydrates to increase vase life and decrease the percentage of dead flowers at termination. Longevity and continued development of cut flowers have been positively correlated with an external supply of carbohydrates (Halevy and Mayak, 1979). Stems in the no-foam treatment with $4.0 \%$ sucrose were able to absorb sufficient solution, but the high concentration of sucrose was detrimental.
Light levels. Flowers that opened under high light in the postharvest environment were darker and more intensely colored than those that opened under low light (Table 6). Griesbach (1992) found that E. grandiflorum flowers that opened under low light were paler than those opening in high light conditions as measured by a photometer microscope. The pale Eustoma flowers contained $70 \%$ less total anthocyanin pigments than darker flowers, and Griesbach (1992) postulated that decreased biosynthesis was the cause of this reduction. Kawabata et al. (1995) found that Eustoma cut flowers were paler under low light than high, and that shading the leaves and stem reduced flower color. Since shading just the flower buds did not change the color and adding 0.5 $\mathrm{M}$ sucrose to the vase solution of flowers under low light produced flower color in cut stems similar to potted plants held in high light conditions, the authors suggested that sucrose supply enhanced anthocyanin synthesis to maintained the expected flower color even under low light conditions. Nowak and Rudnicki (1990) also stated that petal color is positively correlated with the supply of carbohydrates since increased carbon dioxide levels negated the negative effects of shading rose buds during anthocyanin formation. The role of carbohydrates in Campanula flower color may be less clear, as the use of $5 \%$ or $10 \%$ sucrose pretreatments did not produce wellcolored flowers after the start of treatments. The use of 24-h pulse containing sucrose concentrations lower than $5 \%$ but greater than $0 \%$ may be effective, however, in allowing unopened flowers to develop full color.

\section{Literature Cited}

Cavins, T.J. 1999. Cost effective production of specialty cut flowers. MS Thesis, Dept. of Horticulture and Landscape Architecture, Oklahoma State Univ., Stillwater.

Dole, J.M. and H.F. Wilkins. 1999. Campanula, p. 255-260; Postharvest, p. 123-137. In: Floriculture principles and species. Prentice-Hall, Upper Saddle River, N.J.

Goszczynska, D.M. and R.M. Rudnicki. 1988. Storage of cut flowers. p. 35-62. In: J. Janick (ed.). Horticultural reviews, Vol. 10. AVI Publ. Co., Westport, Conn.

Griesbach, R.J. 1992. Correlation of $\mathrm{pH}$ and light intensity on flower color in potted Eustoma grandiflorum Grise. HortScience 27:817-818.

Halevy, A.H., T.G. Byrne, R.E. Hardenburg, A.M. Kofranek, D.S. Farnham, and J.F. Thompson. 1978. Evaluation of postharvest handling methods for transcontinental truck shipments of cut carnations, chrysanthemums, and roses. J. Amer. Soc. Hort. Sci. 103:151-155

Halevy, A.H. and S. Mayak. 1979. Senescence and postharvest physiology of cut flowers, Part I, p. 204-236. In: J. Janick (ed.). Horticultural reviews. Vol. 1. AVI Publ. Co., Westport, Conn.

Han, S.S. 1998. Postharvest handling of cut Heuchera sanguinea Engelm. flowers: Effects of sucrose and silver thiosulfate. HortScience 33:731-733.

Han, S.S., A.H. Halevy, and M.S. Reid. 1990. Postharvest handling of Brodiaea flowers. HortScience 25:1268-1270.

Hunter, D., L. Clark, and M. Reid. 2001. Postharvest handling of campanulas-Watch out for ethylene. Cut Flower Quart. 13(3):23. 
Hunter, R. 1942. Photoelectric tristimulus colorimetry with three filters. U.S. Natl. Bur. Stnd., Circ. C-429, Washington, D.C.

Jones, R. and J. Faragher. 1991. Cold storage of selected members of the Proteaceae and Australian native cut flowers. HortScience 26:13951397.

Kawabata, S., M. Ohta, Y. Kusuhara, and R. Sakiyama. 1995. Influences of low light intensities on the pigmentation of Eustoma grandiflorum flowers. Acta Hort. 405: 173-178.

Kelly, J.W. and T.W. Starman. 1990. Postharvest handling of Physostegia purpurea cut flowers.
HortScience 25:552-553.

Kofranek, A.M. and A.H. Halevy. 1980. Chemical pretreatment of chrysanthemums before shipment. Acta Hort. 113:89-95.

Minolta Corp. 1985. Precise color communication. Minolta Corp., Ramsey, N.J.

Nowak, J. and R.M. Rudnicki. 1990. Postharvest handling and storage of cut flowers, florist greens, and potted plants. Timber Press, Portland, Ore.

Sacalis, J.N. 1993. Cut flowers: Prolonging freshness. 2nd ed. Ball Publ., Batavia, Ill.

Serek, M., E.C. Sisler, and M.S. Reid. 1995. Effects of $1-\mathrm{MCP}$ on the vase life and ethylene response of cut flowers. Plant Growth Regulat. 16:93-97.

Sisler, E.C., M. Serek, and E. Dupille. 1996. Comparison of cyclopropene, 1-methylcyclopropene, and 3,3-dimethlcyclopropene as ethylene antagonists in plants. Plant Growth Regulat. 18:169-174.

U.S. Dept. of Agriculture. 2000. Floriculture crops summary. Natl. Agr. Stat. Serv., Washington, D.C.

Woltering, E.J. and W.G. van Doorn. 1988. Role of ethylene in senescence of petals-Morphological and taxonomic relationships. J. Expt. Bot. 39:1605-1616. 